\title{
ArcheoSciences
}

Revue d'archéométrie

\section{History and Surface Condition of the Lewis Chessmen in the Collection of the National Museums Scotland (Hebrides, late 12th-early 13th centuries)}

Histoire et état de surface des pièces d'échec de l'île de Lewis dans le musée National d'Écosse (Hébrides, fin xiie/début xiiie siècles)

Jim Tate, I. Reiche, F. Pinzari, J. Clark et D. Caldwell

\section{(2) OpenEdition}

Journals

Édition électronique

URL : https://journals.openedition.org/archeosciences/3342

DOI : 10.4000/archeosciences.3342

ISBN : 978-2-7535-1849-0

ISSN : 2104-3728

Éditeur

Presses universitaires de Rennes

Édition imprimée

Date de publication : 30 avril 2011

Pagination : 249-258

ISBN : 978-2-7535-1847-6

ISSN : 1960-1360

Référence électronique

Jim Tate, I. Reiche, F. Pinzari, J. Clark et D. Caldwell, « History and Surface Condition of the Lewis Chessmen in the Collection of the National Museums Scotland (Hebrides, late 12th-early

13th centuries) », ArcheoSciences [En ligne], 35 | 2011, mis en ligne le 30 avril 2013, consulté le 01 mars 2022. URL : http://journals.openedition.org/archeosciences/3342 ; DOI : https://doi.org/ 10.4000/archeosciences.3342 


\title{
History and Surface Condition of the Lewis Chessmen in the Collection of the National Museums Scotland (Hebrides, late $12^{\text {th }}$-early $13^{\text {th }}$ centuries)
}

\author{
Histoire et état de surface des pièces d'échec de l'île de Lewis \\ dans le musée National d'Écosse (Hébrides, fin XII/début XIII siècles)
}

J. Tate* I. Reiche**, F. Pinzari ${ }^{* * *}$, J. Clark* and D. Caldwell *

\begin{abstract}
This paper summarises on-going work to examine the surface condition of the 11 chess pieces in the collection of the National Museums Scotland. The chess pieces are part of the hoard found on the isle of Lewis on the west coast of Scotland and are remarkable examples of medieval ivory carving. The aim of the work is to characterise surface features that can be used to draw new information about the materials from which the pieces were made, their history from the period of their manufacture until they were found in the first part of the $19^{\text {th }}$ century, and whether they were originally coloured. The chess pieces were examined using low-powered optical microscopy and non-destructive X-ray Fluorescence spectroscopy. Modern samples of ivory were exposed to fungi under controlled conditions and the surface damage investigated using optical microscopy and controlled pressure scanning electron microscopy with energy-dispersive X-ray analysis.
\end{abstract}

Résumé : Cet article résume les travaux entrepris pour examiner l'état de la surface des onze pièces d'échecs conservées aux Musées Nationaux d'Ecosse. Ces pièces d'échecs font partie d'un trésor découvert sur l'île de Lewis, sur la côte ouest de l'Ecosse, et forment un exemple remarquable d'ivoire médiéval sculpté. Le but des analyses est de caractériser les éléments de la surface qui permettent d'obtenir des informations sur les matériaux composant les pièces, sur leur histoire, allant de l'époque de leur manufacture à celle de leur découverte au cours de la première moitié du XIX' siècle, et sur leur hypothétique couleur d'origine. Les pièces ont été examinées par microscopie optique à faible puissance et soumises à une analyse non destructrice par fuorescence X. Des échantillons d'ivoire moderne ont été exposés sous contrôle à des moisissures et les dégâts de surface ont été étudiés par microscopie optique ainsi qu'au microscope électronique à balayage à pression contrôlée avec un système d'analyse $X$ dispersif en énergie.

Keywords: Chessmen, Cinnabar, Mycorrhizal fungi, Surface damage, Walrus Ivory, Sperm whale.

Mots clés : Cinabre, Cachalot, Détérioration superficielle, Ivoire de morse, Mycorrhizes, Pièces d'échecs.

\section{INTRODUCTION}

The Lewis Chessmen (Figure 1) are widely recognized to be amongst the most appealing pieces of early medieval sculpture that survive. The miniature figures, each carved in ivory and most less than $100 \mathrm{~mm}$ tall, have charm and individual personalities. Some were clearly for playing chess, the game as we know it being comparatively new in nor-

* National Museums Scotland-Edinburgh, EH5 1JA. (j.tate@nms.ac.uk)

** Laboratoire du Centre de recherche et de restauration des musées de France (LC2RMF UMR 171 CNRS) - Palais du Louvre, 14, Quai François Mitterrand, 75001 Paris.

*** Instituto Centrale per il Restauro e la Conservazione del Patrimonio Archivistico e Librario (ICRCPAL) - via Milano 76, 00184, Rome. 


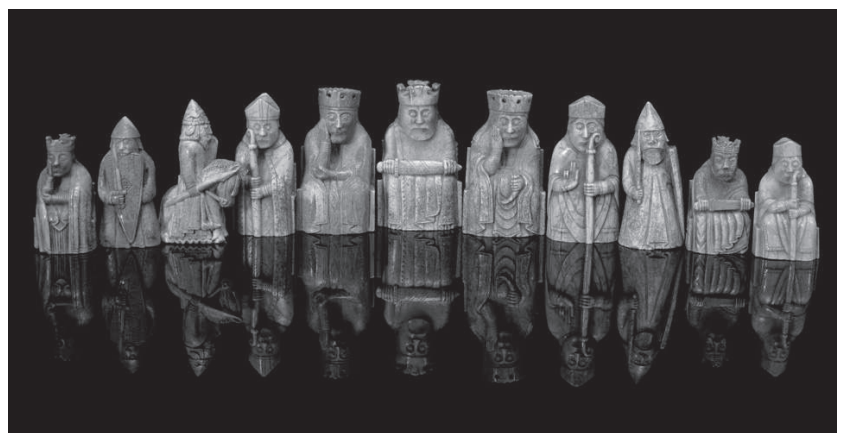

Figure 1: (See colour plate) The 11 chessmen from Lewis in the NMS collection.

Figure 1: (Voir planche couleur) Les onze pièces d'échecs de la collection du Musée National d'Écosse.

thern Europe when they were carved, but other non-figurative pieces in the hoard may well have been for playing the Scandinavian board game hnefatafl (Caldwell et al., 2009). Where and how they were found is uncertain, with various more or less plausible proposals having been enriched by good story telling since the early nineteenth century. Nor do we know for sure where they were made, or for whom, leading to attributions - and claims - from several different countries. Although there are many other carved playing pieces the questions raised by the Lewis hoard continues to intrigue scholars and the public alike, while the figures themselves retain their enigmatic expressions - resigned, worried, fierce, bored, or just generally preoccupied.

It has been generally accepted that the hoard was found in 1831 in Uig, on the west coast of the island of Lewis. Surprisingly there is little direct contemporary evidence, and recent research (Caldwell et al., 2009) has proposed that Mèalasta, still on the coast but several miles south of Uig Strand, is possibly a more likely location. It was not long before various different legends about their finding became established. Madden (1832) says that they were found by a "peasant... while digging a sand bank". Wilson (1851) says that the peasant found the pieces in a "small subterranean stone building like an oven, some depth beneath the surface". By 1861 Thomas (1863) reported an earlier and far more elaborate story told by Donald Morrison who died in 1834 , which starts in the early $17^{\text {th }}$ century with a seaman escaping from a shipwreck with a bag containing "the wealth the ship was supposed to contain". The sailor was observed and killed, but when the contents of the bag were examined his murderer decided that they were too incriminating and went some 10 miles to bury them in a sand bank in Uig - where they remained until found in 1831 by Malcolm Macleod. Robinson (2009) notes how a cow joins into the story in other versions, while both he and Caldwell et al. (2009) point out that the tales say more about the significance of story telling in the Hebrides than about the history of the pieces.

Even after they were discovered the history of the pieces has some gaps. They were acquired from the finder by Roderick Ririe, who permitted their display in Edinburgh in April 1831 and then bought by T A Forrest who, after failing in Edinburgh, successfully sold the majority of them to the British Museum. Thus 82 pieces (6 Kings, 5 Queens, 13 Bishops, 14 Knights, 10 Warders, 19 Pawns or games pieces, and a small belt buckle also in ivory) were acquired by the BM in 1831/2 and were comprehensively published by the Keeper Sir Frederick Madden (Madden, 1832).

However, Ririe had a further 11 pieces (10 from the hoard and a further piece which he obtained from Lewis) which he sold to Charles Kirkpatrick Sharpe, an Edinburgh dealer. These pieces remained with Sharpe until 1851 when they were sold to Lord Londesborough, in whose collection they remained until eventually, in 1888, they were acquired by the National Museum of Antiquities of Scotland, now the National Museums Scotland (NMS): 2 Kings, 3 Queens, 3 Bishops, 1 Knight and 2 Warders.

The collecting history of the chess pieces has been outlined to illustrate that there are several possible scenarios in the life of the pieces since they were carved in the late $12^{\text {th }}$ or early $13^{\text {th }}$ century and deposited (however this came about) in the hoard not long afterwards (Caldwell et al., 2009 and 2010). Were they buried in a sand dune, or in a vaulted chamber? Does the buckle mean that some or all were together in a bag? Were they recovered earlier than 1831 and kept in different conditions? And when they moved into private and public collections what was done to clean and preserve them?

The purpose of this study on the 11 pieces now in the NMS collection was to see whether the surface condition of the pieces might help to understanding their history. The pieces have often been illustrated and described (Glenn, 2003; Stratford, 1997; Robinson, 2009; Caldwell et al., 2009 and 2010) as well as being on permanent display. However, for the reasons outlined above they were not included in the first and fullest account by Madden (1832) who noted particularly how a number of the pieces newly acquired by the BM had traces of red colour. Nor were the NMS pieces included in the technical examination undertaken at the BM department of scientific research reported by Stratford (1997). A more comprehensive study is now planned of the full collection from the hoard in both museums to allow more detailed comparison of the surface 
appearance and condition and particularly to relate this to different cleaning and conservation treatments since they were collected.

The work so far has considered four questions:

- Are the pieces all from Walrus ivory, and can we say anything about the tusks they came from?

- Are there tool marks that might distinguish working methods?

- What is the nature of the surface damage and can that tell us anything about the environment to which they have been subjected?

- Is there any remaining evidence of colouring?

All eleven pieces from the NMS collection were examined, ie

Kings H.NS 19 and H.NS 20

Queens H.NS 21, H.NS 22 and H.NS 23

Bishops H.NS 24, H.NS 25 and H.NS 26

Knight H.NS 27

Warders H.NS 28 and H.NS 29

\section{Methods}

\section{Investigations of Lewis chess pieces}

The pieces were examined with an Olympus SZX12 stereo microscope with magnification between $\mathrm{x} 7$ and $\mathrm{x} 50$ with direct observation, digital image capture and linear measurement using AnalySIS software.

Selected areas of the pieces were examined using X-ray Fluorescence (XRF) with a modified Oxford Instruments ED 2000 with Oxford Instruments software ED 2000SW version 1.31 with open sample geometry and a short airpath between sample and X-ray source and $\mathrm{Si}(\mathrm{Li})$ detector. Standard conditions use a Rhodium X-ray tube at $48 \mathrm{kV}$ and up to $1 \mathrm{~mA}$, the primary beam exciting an analytical area approx $2 \times 3 \mathrm{~mm}$ on the sample, the position of the analysis shown by the intersection of two laser pointers. The system detects atomic number elements greater than 19, the detection limits and analytical depth depending on the sample matrix. Data are recorded as energy spectra between 3 and $40 \mathrm{keV}$ with a detector energy resolution of $140 \mathrm{eV}$ at $6 \mathrm{keV}$. In order to compare results from different analyses net peak area values were extracted and presented either as ratios, or by comparison normalised to the main $\mathrm{K}$-alpha peak from Calcium.

\section{Artificial fungal aging experiments on modern ivory}

A boar (Sus scrofa, L.) tusk about 30 years old was used for the investigation of the effect of fungi damage on ivory. Cut into $1-2 \mathrm{~cm}$ diameter pieces the tusk was cleaned with ethanol 70\% (water:alcohol V:V), sterilised under $254 \mathrm{~nm}$ UV light for 45 minutes at approx $40 \mathrm{mWs}^{-1} \mathrm{~cm}^{-2}$. They were separated into two experiments. Two pieces were inoculated with an Aspergillus niger van Tieghem strain (from the ICRCPAL culture collection) and placed in sterilised Petri dishes at $100 \% \mathrm{RH}$ at $25^{\circ} \mathrm{C}$ for 10 days along with 2 controls with no inoculation. Further pieces were treated in the same way but immersed in nutritive agar. Full details will be given in Pinzari et al. (forthcoming).

The ivory samples were examined by optical microscopy before and after fungal growth using a Leica MZ16 stereoscopic microscope fitted with low temperature fibre optic illumination. The system was equipped with a digital camera connected with a computer and software (L.A.S. Leica) that allow the multifocal composition of images.

The samples were also analysed before and after fungal growth using a Carl-Zeiss EVO50 variable pressure scanning electron microscope (VP SEM) with a backscattered electron detector (BSE) and Oxford Instruments INCA 250 energy dispersion spectroscopy (EDS).

\section{Results ANd Discussion}

\section{The species of ivory and possible location within the tusk.}

The chess pieces are generally referred to as being made from Walrus ivory, with a few possibly of whale tooth. A characteristic of walrus ivory is that the main bulk of the tusk consists of dentine that is clearly divided into two forms, the outermost primary dentine which is smooth and uniform, and an inner secondary dentine which has a granular "oatmeal" like structure (Webster, 1958; Locke, 2008). In section the tusks are oval and the distinction between the different dentine layers can be clearly seen. In contrast sperm whale teeth are more uniform, with a more circular cross section with concentric growth rings (eg Espinoza and Mann, 1991). Elephant and hippopotamus ivory have characteristic forms, although their identification is not always straightforward, but it is known that these materials were very scarce in northern Europe in the $11^{\text {th }}$ and $12^{\text {th }}$ centuries (Robinson, 2009). Walrus ivory and whale teeth are hollow 
at the base pulp cavity, becoming solid in moving towards the distal end. Narwhale tusks are smaller in diameter with a hollow core along the bulk of their length.

We do not have polished cross sections of the Lewis chess pieces but the bases do provide evidence of characteristic differences. The base of the King (H.NS 19, Figure 2a) shows the roughly oval shape of the darker patterned secondary dentine at the centre, surrounded by paler primary dentine. For the Queen (H.NS 23, Figure 2b) the same structure is clear, the void showing that the piece was carved from the proximal end of the tusk where the formation the globular secondary dentine starts. However the Warder (H.NS 28, Figure 2c) has a quite different base; the conical void is surrounded by a more circular structure as well as being a paler chalk-like colour. The second Warder (H.NS 29, Figure 3a) was at one point classified as whale tooth: however the base shows quite clearly the secondary dentine structure of walrus.

The material of the only Knight in the NMS collections (H.NS 27, Figure 3b) is less clear. While the overall shape suggests the likely use of a wide walrus tusk, the appearance of the surface is more chalk-like than the other walrus pieces, and the pattern on the base less diagnostic of the species. It is in generally poor condition, with material loss and serious longitudinal cracking.

To carve the pieces the craftsman had to remove significant depths of ivory from the surface: for example in the King (H.NS 19) each side of the face is about $15 \mathrm{~mm}$ deeper in that the sides of the throne, and there is a similar depth between the front of his chest and his knees. The carver did not avoid cutting through the primary dentine to expose the marbled secondary dentine layer. On what we might see as the "better" pieces this has been minimised so that, for example, the King's face is smooth and the secondary dentine is only apparent as a band up the sides and across the top of the head. This is similar for one of the Queens and the three Bishops. For the other King (H.NS 20) and two Queens there is considerably more secondary dentine exposed (Figure $4 \mathrm{a}$ and $\mathrm{b}$ ); this might have been because the carver appreciated the contrasting effect, was simply less skilled, or because the ivory available had a thinner primary dentine layer.

In contrast the smaller NMS Warder (H.NS 29) only shows the secondary dentine at the base, very little is revealed near the head (Figure 4c). We conclude that this piece was carved from the distal end of the tusk, passing the upper reach of the secondary dentine. An X-ray radiograph taken of natural walrus tusk specimens does not clearly reveal the extent of the secondary dentine, the small difference in density being masked by longitudinal surface cracks and marks. Interestingly the radiograph does reveal cracks across the inner part of the tusk, suggesting that the secondary dentine is separating and therefore may well be fragile. Some indication of such cracks was also found on a small sample of sectioned tusk in the NMS collection.

Clearly the form of the pieces depended on the nature and quality of the tusk that the carver had available. Robinson (2009) illustrates how several pieces might have fitted in to one tusk, and Poplin (2006) has pointed out how two of the Bishops in the BM collection appear to have been carved back-to-back from the same piece of tusk. Since the cross-section of the primary/secondary interface has quite varied shape and dimensions there does seem to be scope for investigating this more closely with a view to matching pieces. High resolution Computerized X-ray tomography (CT) scanning offers a possible way of obtaining virtual cross-sections to allow comparison and potential matching of any pieces from the same tusk (Reiche et al., 2011).

As part of the overall examination of the pieces using X-Ray Fluorescence (XRF) we compared the relative amounts of
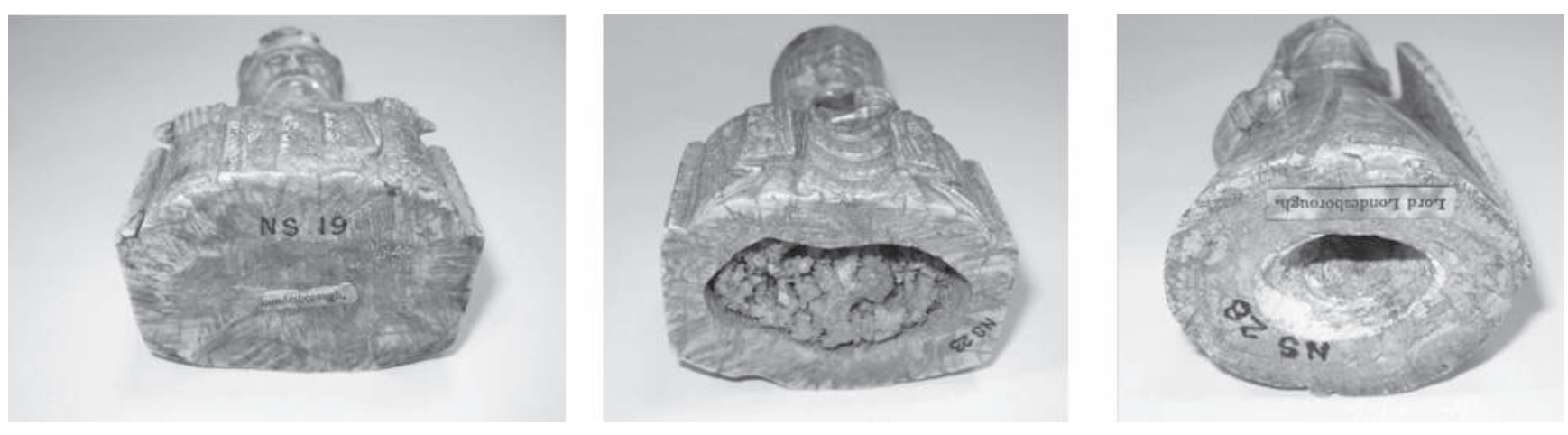

Figure 2: (a) Base of King (H.NS 19) (b) Base of Queen (H.NS 23) (c) Base of Warder (H.NS 28).

Figure 2 : (a) Base du Roi (H.NS 19). (b) Base de la Reine (H.NS 23). (c) Base du Gardien (H.NS 28). 

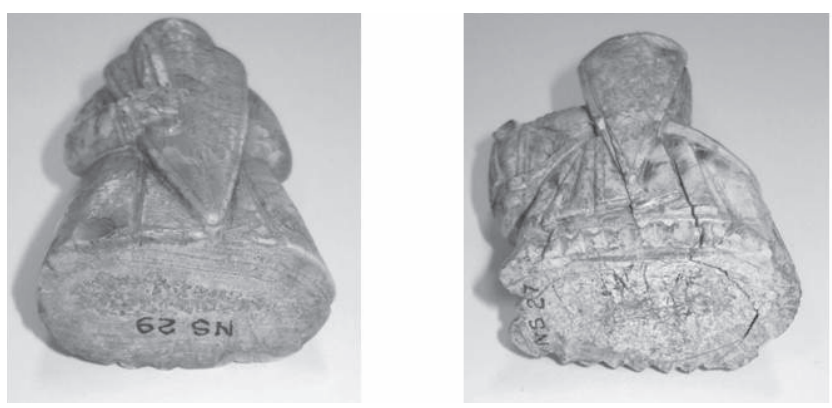

Figure 3: (a) Base of Warder (H.NS 29) (b) Base of Knight (H.NS 27).

Figure 3 : (a) Base du Gardien (H.NS 29). (b) Base du Cavalier (H.NS 27).
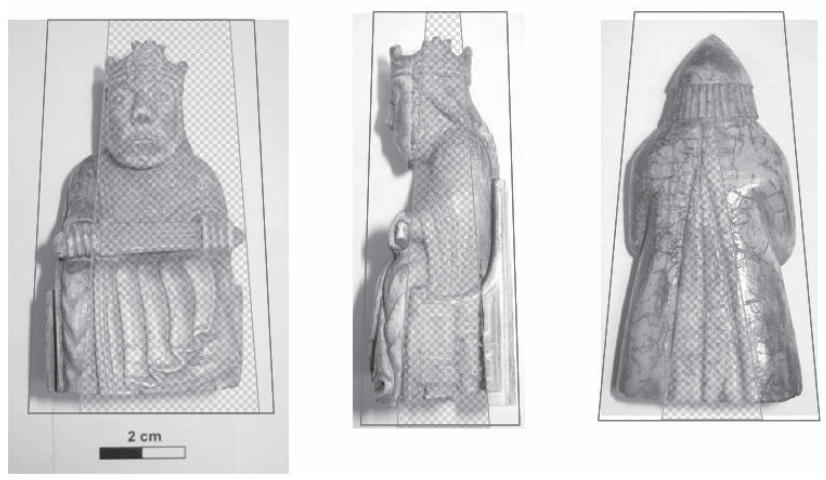

Figure 4: (a \& b) Showing how King (H.NS 20) has been cut partially through the secondary dentine, while (c) the Warder (H.NS $28)$ is almost entirely from primary.

Figure 4: (a \& b) image montrant comment le Roi (H.NS 20) a été partiellement sculpté dans la dentine secondaire, alors que le Gardien (H.NS 28) est presque entièrement sculpté dans la dentine primaire.

Calcium $(\mathrm{Ca})$ and Strontium $(\mathrm{Sr})$ in the different chess pieces. The average relative values for each chess piece are shown in Figure 5. These measurements were made on various parts of the chessmen rather than concentrating on the directly comparable areas of each (such as the cut base) and have a certain amount of scatter. Nevertheless they show that two of the pieces have a lower $\mathrm{Ca} / \mathrm{Sr}$ ratio than the first eight. We made the same measurements on three specimens of walrus tusk and three whale teeth from the collections, and found that, from this small sample, the whale teeth had a lower $\mathrm{Ca}$ / $\mathrm{Sr}$ ratio. We cannot obtain quantified data for $\mathrm{Ca}$ and $\mathrm{Sr}$ from the XRF data obtained in these experiments, nor can we separate surface and bulk compositional differences, and we report the data simply as a qualitative observation. The existence of strontium within bone and enamel has been extensively studied in relation to the determination of diet from ${ }^{87} \mathrm{Sr} /{ }^{86} \mathrm{Sr}$ isotopic ratios, with attention particularly to the relative sta-

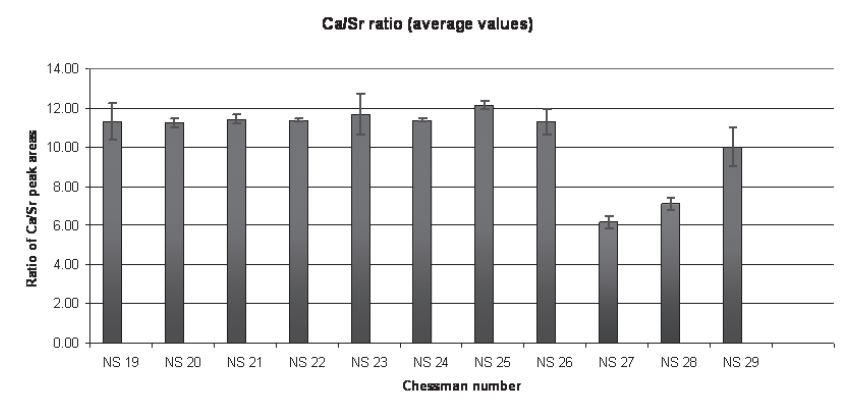

Figure 5: (See colour plate) The ratio of Calcium to Strontium as measured by XRF from various locations on each chess piece. The lower values for H.NS 27 and H.NS 28 correspond to lower ratios found for whale teeth compared to walrus tusks.

Figure 5: (Voir planche couleur) Le rapport calcium sur strontium mesuré par fluorescence $X$ à divers endroits sur chaque pièce. Les valeurs moins élevées pour H.NS 27 et H.NS 28 sont en accord avec les valeurs moins élevées enregistrées pour les dents de cachalot comparées à celles des défenses de morse.

bility within the matrix of $\mathrm{Sr}$ arising from diet or from post mortem burial environment (eg Sillen and Kavanagh, 1982; Burton and Wright, 1995; Burton et al., 1999; Budd et al., 2000; Price et al., 2002; Lee-Thorpe, 2008). Godfrey et al. (2002) record low values (200ppm) of Sr for modern elephant ivory and higher (720 to $1440 \mathrm{ppm}$ ) for elephant ivory recovered from a $17^{\text {th }}$ century shipwreck, presumably showing the effect of prolonged immersion in sea water. As both walrus and sperm whale are marine animals fairly high levels of Sr are not unexpected and although we do not know the impact of their habitats, different feeding regimes or diagenesis, Müller and Reiche (2011) have also noted different $\mathrm{Sr} / \mathrm{Ca}$ ratios from sperm whale compared to other marine ivory in a study using PIXE/PIGE of a wider range of samples. It seems reasonable therefore for us to hypothesise that both the Warder (H.NS 28) and the Knight (H.NS 27) are whale tooth, while the Warder (H.NS 29) is walrus ivory like the other pieces.

\section{Surface evidence of tool marks}

As outlined above we know nothing about the chessmen between the time they were lost or buried and their finding in 1831 . We do not know if they were continuously buried until they were found, or if they might have spent some of the time between being abandoned (presumably in the $13^{\text {th }}$ century) and found (in $19^{\text {th }}$ century) in different burial conditions and environments. Anything that we can deduce from the condition of the chess pieces which will tell us about the environments to which they have been exposed will increase our understanding of the history of the pieces. 
Visual and microscopic examination of the surface shows evidence firstly of tool marks as quite coarse grooves, presumed to be from fine chisels with slightly damaged cutting edges (Figure $6 a)$. These marks suggest tools of less than $0.5 \mathrm{~mm}$, the main decorative grooves are typically 0.2 to $0.3 \mathrm{~mm}$ wide at their base. There are also groups of parallel scratches oriented in different directions from polishing or fine scraping to achieve the smooth surfaces, individual scratches being around $0.1 \mathrm{~mm}$ (Figure $6 \mathrm{~b}$ ). These marks, and the way in which the ivory has been cut to highlight features, for example the sharpness of the cutting lines around the eye lids, could be used to compare tools between pieces, something which was not possible in the limited time available for this study.

Groups of parallel "chatter marks" were also observed on otherwise smoothed surfaces (Figure 6c). The marks look at first like the impressions that might come from vice marks, the short parallel lines forming tracks like the scale of a ruler. The separation of the lines varies between 50 and $300 \mu \mathrm{m}$, consistent within each track but apparently with no basic size "unit" between tracks. We conclude that they are caused by a blade vibrating as it is dragged across the ivory surface, the frequency of vibration depending on the pressure, the characteristics of the blade and the structure of the ivory. We have observed that similar marks occur on other pieces of cleaned or worked ivory.

\section{Other surface damage}

The chess pieces all exhibit even more prominent and very characteristic damage: the surfaces are covered with a network of fine channels (Figures 6 and 7). These channels
- are typically $0.5 \mathrm{~mm}$ across and of a similar depth, none are bore holes

- wander irregularly across the surface

- vary in length - some are just spots, while others can be followed for several millimetres

- cross and join together, or sometimes run side by side, but do not have any systematic branching form, nor is there any tapering of the widths along the length of the tracks

- have rough edges and grainy bottoms with dark mineral inclusions

- cover pretty much all surfaces evenly, there are very few sides of any of the chess pieces that do not have this damage, including the bases.

The damage must have occurred after the pieces were carved. It is evident from simple visual examination that the channels cause disfigurement to the carved and polished surfaces. For example, the face of the King (H.NM 19, Figure $7 \mathrm{a})$ has a groove on one cheek: it is hard to imagine that the carver would have left such a scar. The damage is on surfaces that have only been revealed because the overlying ivory material has been removed during carving, and there are no bore holes into the ivory on the areas which were closer to the outer original surface. We can also see examples where some of the channels cross over carved details: for example across the sharply carved hair of Bishop (H.NS 25, Figure $7 b)$.

The tracks have been attributed to "the burrowing of tiny termites such as are common in sand" (Stratford, 1997) "etching by acids secreted by plant rootlets or alternatively by grazing organisms" (Stratford, 2001) and "the burrowing action of insects that live in the sand" (Robinson, 2009).
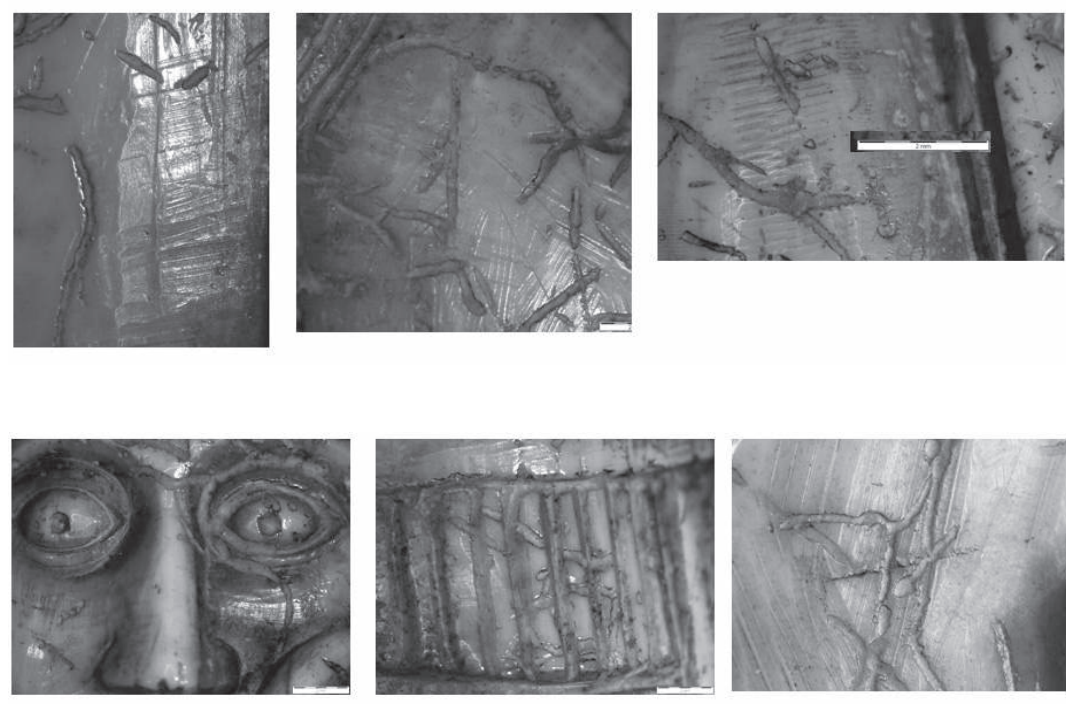

Figure 6: (a) Surface tool marks where material has been cut away. (b) polishing marks as groups of fine abrasions in different orientations. (c) "chatter" marks, coarse marks towards the centre, and a finer band down the left of the image. Figure 6: (a) Traces d'outil à la surface, où le matériau a été découpé. (b)Traces de polissage : groupes d'abrasions fines dans des directions multiples. (c) Marques accidentelles d'outil, épaisses vers le centre, avec une bande plus fine sur la gauche de l'image.

Figure 7: (a) post polishing damage channel on the cheek and (b) carved hair. The channels cross rather than branch (c).

Figure 7 : (a) Canal de détérioration postérieur au polissage situé sur la joue et (b) sur la chevelure sculptée. Les canaux se recoupent plutôt que de se ramifier. 
Although the damage tracks look very like those found on organic material, especially beneath the bark layer of wood, there are no insects that eat ivory in a similar way. Marine polychaets digest minerals, for example limestone, producing both surface channels and holes and tunnels. These may be of similar dimensions to the chessmen tracks, but the fact that they burrow into the stone is quite different from the surface channels on the chess pieces, and the condition of the chessmen is not like that of ivory which has been submerged in salt water for any length of time (Godfrey et al., 2002) and without traces or marks, such as biogenic calcareous material, which would be expected from a marine environment. Cliona (marine sponges) also cause damage but more as spots rather than tracks. Uncarved walrus tusks in the natural history collections of NMS did not reveal any with similar channelling on the visible surfaces, suggesting that this type of damage does not occur during the life of the animal when marine exposure is of course the norm.

We have however found examples of very similar damage on a fragment of boar tusk excavated from Cnip on Lewis (Lelong, 2010), a site only a few miles along the coast from Uig bay. This fragment shows a higher level of damage, in terms of channel density, than the chessmen. Unfortunately, it does not have a secure date from the stratigraphy of the excavation and may come from an earlier period.

As noted the sides of the channels are often stained or "dirty" looking and there are small dark particles which appear to be enclosed in the mineral material, suggesting that an intimate relationship with the soil has occurred. This, together with the dimensions and the overlapping is consistent with damage caused by chemical action of a tightly overlapping root system. The chemotrophic activity of roots is documented, especially in poor, sandy soils (Crowther, 2002) where dissolution of calcitic material by the combination of the root and associated fungi (mycorrhizas) can take place. There is a considerable literature concerning the damage to buried bone from roots, fungi and microbacteria, but little that considers damage to ivory. The action of fungi alone is possible, but in itself seems unlikely to lead to channels of the size observed, while microbacterial attack leads to pits and staining rather than channels.

In bone the damage caused by roots is reported as leading to tunnelling as well as surface damage, presumably because of the more porous nature of the bone surface compared to ivory (Grupe and Dreses-Werringlöer 1993). Acid soils are generally considered to favour bone pitting by roots and fungi, and there are of course differences according to the plant species (Binford, 1981; Swift et al., 1979). It has been suggested that in some nutrient-poor soils mycorrhizal fungi may have direct involvement in bone decomposition caused by the excretion of acid metabolites (Marchiafava et al., 1973; Grupe and Dreses-Werringlöer, 1993).

\section{Results from preliminary experiments on modern ivory}

The control samples, inoculated only with broth, showed no alteration of the surface. Samples of ivory inoculated with Aspergillus niger showed tunnelling on the dentine layer and a change in microscopic surface appearance. Fungal mycelia formed a dense layer around the whole sample and a subtle white crust appeared raised from the ivory surface in some points of the sample. Variable pressure SEM examination revealed that the white crusts are made of biogenic crystals produced in the fungal matter and presumably leached from the ivory surface. The appearance of the crystals precipitated between hyphal matter resemble calcium oxalate, while the crystals that cover the surface of the sample and that crystallize on fungal hyphae have the appearance of calcite. The surface of the samples was covered by a dense pattern of crystals and crossed by channels, tracks and calcified hyphae (Figure 8).

Energy dispersive microanalysis confirmed the elemental composition of the different crystalline areas, and also showed that the action of the fungi is to selectively leach calcium (Ca) from the body of the tusk to form calcite crystals on the surface: Phosphorus $(\mathrm{P})$, which is clearly present

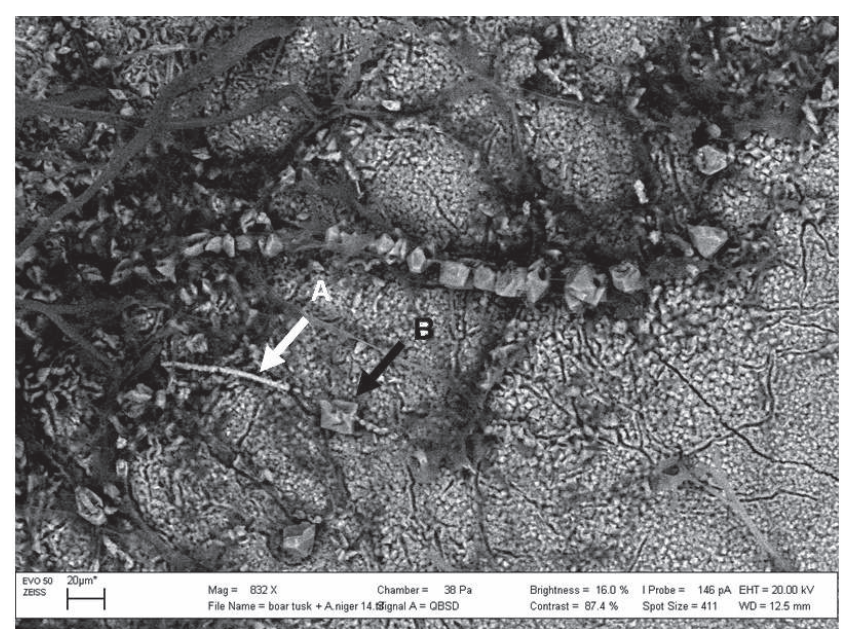

Figure 8: VP-SEM BSE electron micrograph of ivory surface after fungal growth. Calcified fungal hyphae (A) and calcium oxalate crystal (weddellite) (B) are present (arrows).

Figure 8 : Micrographie électronique obtenue en mode BSE de la surface d'un échantillon d'ivoire après culture fongique. Des hyphae fongiques calcifiés (A) et un cristal d'oxalate de calcium (weddellite) (B) sont également présents (voir flèches). 
in the un-attacked tusk, does not occur in the new surface layer (Figure 9).

The metabolic activity of fungi has been found to be implicated in the biodeterioration of cultural monuments causing pitting, encrustations and discolouration (Sterflinger 2000). Among pitting causing fungi, Aspergillus niger has been widely studied for enzymatic formation of oxalate from oxaloacetate (Gadd, 2007) and its ability in biochemical transformation of rocks. Our results demonstrate that Aspergillus niger causes similar leaching of apatite from ivory and the biogenic formation of new minerals such as calcium oxalates: if these minerals can be detected in future analysis of the chessmen their existence could be taken as reasonable proof of fungal activity on the surface.

These experiments are in progress and will be reported on in a later paper (Pinzari et al., forthcoming). As noted we do not anticipate that fungi alone can produce large tunnelling and plan therefore to extend the experiment using soil and the marram grass (Ammophila spp.) typical to the west coast of Lewis. With these experiments we aim to reproduce the track formation and establish parameters for the rate of damage, information which may allow some estimation of the length of time the chessmen would have been exposed to this type of burial condition. We will also be able to examine the track damage in more detail, particularly using VP-SEM-EDS and possibly both FTIR and Raman spec-

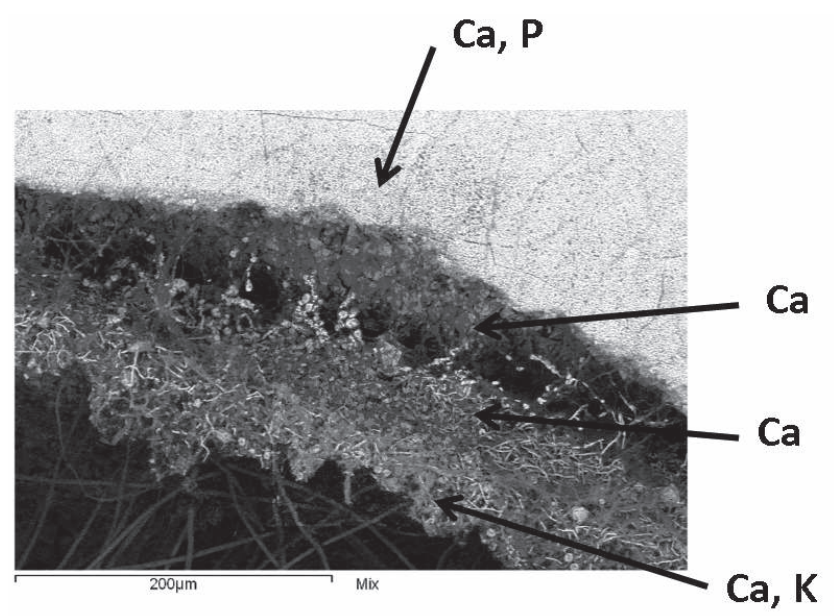

Figure 9: (See colour plate) V-SEM-EDS elemental map for Calcium (Ca), Phosphorous (P) and Potassium (K) across edge of ivory sample showing selective leaching of $\mathrm{Ca}$ into the fungi mat. Figure 9: (Voir planche couleur) Cartographies chimiques obtenues au microscope électronique montrant la répartition du calcium (Ca), phosphore $(P)$ et potassium $(K)$ d'un échantillon d'ivoire vu en coupe, et mettant en évidence l'extraction sélective du calcium par l'enchevêtrement fongique. troscopy to characterise changes of the organic and inorganic composition induced.

\section{Physical damage}

For playthings the chess pieces are in remarkably good physical condition. Generally the damage is more from the environment to which they must have been exposed (detailed above) than to abrupt physical stress or knocks which might be expected from extensive handling. However, on some pieces such as the knight H.NS 27, which is in quite poor condition compared to the other pieces, discolorations and cracks might be due to fire-damage. This hypothesis needs however to be confirmed by more detailed investigations of heat-induced damage of different types of ivory.

It may be that only those in good condition were gathered in the hoard, but it seems that they must have been well cared for. There has been erosion of some of the surface details, some pieces have splits and lifting surfaces, and there is surface discolouration or staining. Where there is physical damage, such as the chipped crown of King H.NS 19, some of this may well have occurred after the pieces were found in 1831 .

The pieces might have had some protection if they were wrapped or enclosed in a bag. The ivory buckle found with the hoard may have come from a textile or leather bag which subsequently decayed providing an organic layer attractive to plant roots and fungi. As noted, the channel damage covers all surfaces of the chess pieces, meaning that they would have to have been tightly surrounded with roots. They could have been re-positioned in moving sand, although we might expect any significant changes - for example if they were in a sand dune that was eroded by the wind so that they were occasionally exposed - to have led to more surface abrasion. If all were wrapped tightly together in one bag it might be expected that some areas would be protected from exposure to roots. Perhaps then they were initially fairly loosely together, possibly individually wrapped, in a bag or bags. To be damaged by roots they must all have been at about the same depth in the sand: and because each channel is presumably the action of an individual root tip over a growing season they might not have been within an active root system for the whole period of burial.

\section{Colour}

A particularly interesting outcome of this study has been finding traces of mercury on various parts of the surface of individual pieces by XRF analysis. This will be reported 
in detail elsewhere (Tate et al., forthcoming) and we note here simply the finding and the exciting conclusion that the mercury comes from traces of cinnabar, a mineral well known to have been used as a red pigment in the medieval period (Eastaugh et al 2004). In his 1832 report on the chess pieces acquired by the British Museum, Madden says "For the sake of distinction, part of them were originally stained of a dark red or beet-root colour; but from having been so long subject to the action of the salt-water, the colouring matter, in most cases, has been discharged" (Madden, 1832 p. 212). No traces of this colour can now be convincingly seen, (although we would not expect it still to look red [McCormack, 2000]) nor could any be found when the British Museum undertook a comprehensive study of the pieces (Stratford, 2007 p. 55 and Higgitt, 2010). However this is the first time that the NMS pieces have been analytically examined and it may be that the traces we have found reflect the rather different treatment that the two groups of chess pieces have received since they were found. There was insufficient time in the scope of our study to map the distribution of $\mathrm{Hg}$ across the pieces and to draw any conclusions about the extent of decoration, or any correlation with the density of the damage tracks. Both of these are planned for a further in-depth study.

\section{Conclusions}

In this preliminary study we have clarified that while nine of the eleven chess pieces in the NMS collection are made from walrus ivory, two are different and most probably are sperm whale teeth, basing this conclusion on a combination of visual examination and non-destructive elemental analysis. We confirm the presence of working tool marks in the ivory and the possibility of their being used to compare the tools used on different pieces, including the existence of mechanical looking striations which we believe to be "chatter marks" from surface scrapers. We have recorded the characteristics of the surface "channels" which we believe most likely to be the action of ectomycorrhizal fungi associated with plant rootlets. We have completed a preliminary experiment to demonstrate the action of fungi on boar tusk ivory and are investigating this further with walrus ivory and the flora on Lewis to learn about the environmental exposure of the pieces. And finally we note the detection of traces of what we believe to be cinnabar, evidence found for the first time that the pieces were at least partly decorated with red pigment.

\section{Acknowledgements}

Many people have contributed with suggestions during this study, and we would like to thank particularly Prof M Gadd, Dr J Herman, Dr A Kitchener, Dr S Kirk, Dr R Galera, L Troalen, J Moran, D McLaren, Dr S Walsh, Dr R Lyszkowski, Dr M Holdsworth, A. Gilbert and Dr C. Higgitt for their participation and enthusiastic help. We would like to thank the referees for helpful comments which have improved the text.

\section{References}

Binford, L. R., 1981. Bones: Ancient Men and Modern Myths. New York, NY: Academic Press.

Budd, P., Montgomery, J., Barreiro, B. and Thomas, R. G., 2000. Differential diagenesis of strontium in archaeological human dental tissue. Applied Geology 15: 687-694.

Burton, J. H. and Wright, L. E., 1995. Nonlinearity in the Relationship Between Bone Sr/Ca and Diet: Paleodietry Implications. American Journal of Physical Anthropology 96: 372-282.

Burton, J. H. Price, T. D. and Middleton, W. D., 1999. Correlation of Bone $\mathrm{Ba} / \mathrm{Ca}$ and $\mathrm{Sr} / \mathrm{Ca}$ due to Biological Purification of Calcium. Journal of Archaeological Science 26: 609-616.

Caldwell, D. H. C., Hall, M. A., and Wilkinson, C. M., 2009. The Lewis Hoard of Gaming Pieces: A Re-examination of their Context, Meanings, Discovery and Manufacture. Medieval Archaeology 53: 155-203.

Caldwell, D. H. C., Hall, M. A., and Wilkinson, C. M., 2010. The Lewis Chessmen Unmasked. NMS Enterprises, Edinburgh.

Crowther, J., 2002. The Experimental Earthwork at Wareham, Dorset after 33 Years: Retention and Leaching of Phosphate Released in the Decomposition of Buried Bone. Journal of Archaeological Science 29: 405-411. doi:10.1006/ jasc.2002.0728, available online at [http://www.idealibrary. com].

Eastaugh, N. Walsh, V., Chaplin, T. and Siddall, R., 2004. The Pigment Compendium. Elsevier Butterworth-Heinemann.

EspinOzA, E. O. and MAN, M. J., 1991. Identification guide for ivory and ivory substitutes. World Wildlife Fund and Conservation Foundation. Baltimore.

GADD, G. M., 2007. Geomycology: biogeochemical transformations of rocks, minerals, metals and radionucides by fungi, bioweathering and bioremediation. Mycological Research 111: 3-49.

GLEnN, V., 2003. Romanesque and Gothic. NMSE Publishing, Edinburgh. 
Godfrey, I. M., Ghisalberti, E. L., Beng, E. W., Byrne, L. T. and Richardson, G. W., 2002. The analysis of ivory from a marine environment. Studies in Conservation 47: 29-45.

Grupe, G. and Dreses-Werringlöer, U., 1993. Decomposition phenomena in thin sections of excavated human bones, in $\mathrm{G}$. Grupe and A. N. Garland, (eds), Histology of Ancient Human Bone: Methods and Diagnosis. Berlin: Springer-Verlag.

Higgitt, C., 2010. Personal communication.

Lee-Thorpe, J. A., 2008. On Isotopes and Old Bones. Archaeometry 50 (6): 925-950.

LeLong, Personal communication 2010.

Locke, M., 2008. The structure of Ivory. Journal of Morphology 269: 423-450.

Marchiafava, V., Bonucci, L. and Acenzi, A., 1974. Fungal Osteoclasia: a model of dead bone resorption. Calcified Tissue Research 14: 195-210.

MAdDEN, F., 1832. Historical Remarks on the introduction of the game of Chess into Europe, and the ancient chess-men discovered in the Isle of Lewis. Archaeologica 24: 203-291.

McCormack, J. K., 2000. The darkening of cinnabar in sunlight. Mineralium Deposita 35: 796-798.

Müller, K. and Reiche, I., 2011. Differentiation of archaeological ivory and bone materials by micro-PIXE/PIGE with emphasis on two Upper Paleolithic key sites at Abri Patuad and Isturitz, France. Journal of Archaeological Science, doi:10.1016/j.jas.2011.06.029.

Pinzari, F., Bicchieri, M., Gadd, G. and TAte, J. (in preparation).

Poplin, F., 2006. L'ivoire de rhinocéros et les ivoires du ProcheOrient ancien. Comptes Rendus de l'Académie des Inscriptions 1116:1130.
Price, T. D., Burton, J. H. and Bentley, R. A., 2002. The characterisation of biologically available strontium isotope ratios for the study of prehistoric migration. Archaeometry 44 (1): 117-135.

Reiche, I., Müller, K., Staude, A., Goebbels, J. and Riesemeier, H., 2011. Synchrotron radiation and laboratory micro X-ray computed tomography - useful tools for the material identification of prehistoric objects made of ivory, bone or antler. Journal of Analytical Atomic Spectroscopy, doi:10.1039/ c0ja00246a.

Robinson, J., 2009. The Lewis Chessmen. BM Press.

Sillen, A. and Kavanagh, M., 1982. Strontium and Palaeodietry Research: A Review. Yearbook of Anthropology 25: 67-90

Sterflinger, K. and Claeys, P., 2005. Fungi as geological agents. Geomicrobiological Journal 17: 97-124.

STratford, N., 1997. The Lewis Chessmen and the enigma of the hoard. BM Press.

Swift, M. J., Heal, O. W. and Anderson, J. M., 1979. Decomposition in Terrestrial Ecosystems. Oxford: Blackwell Scientific Publications.

Tate, J., Reiche, I., and Pinzari, F. (forthcoming). The Lewis Chessmen: What can examination of the surfaces tell us? In The Lewis Gaming Hoard in Context - new analyses of their art, purpose and place in history. Ed Caldwell D. H. and Hall M.

Thomas, 1863. Notes on the Lewis Chessmen. PSAS iv 1860-1862, 411-413.

Webster, R., 1958. Ivory Bone and Horn. The Gemmologist 27: 91-98.

Wilson, D., 1851. The Archaeology and Prehistoric Annuals of Scotland. Edinburgh. 